Dostępne online www.journals.wco.pl/los

Zeszyty Naukowe WCO, Letters in Oncology Science 2020;17(3):1-7

CrossMark

\author{
Praca poglądowa/Review paper
}

\title{
Przydatność badania PET/CT w diagnostyce chłoniaka Hodgkina
}

\section{The utility of the PET/CT method in Hodking's lymphoma diagnosis}

\author{
Roksana Zając ${ }^{1}$, Agata Karolina Pietrzak², Witold Cholewiński ${ }^{3}$ \\ ${ }^{1}$ Student kierunku Elektroradiologia, Katedra i Zaktad Elektroradiologii, \\ Uniwersytet Medyczny im. K.Marcinkowskiego w Poznaniu \\ ${ }^{2}$ Katedra i Zakład Elektroradiologii Uniwersytetu Medycznego im. K. Marcinkowskiego w Poznaniu \\ ${ }^{3}$ Katedra i Zakład Elektroradiologii Uniwersytetu Medycznego im. K. Marcinkowskiego w Poznaniu
}

\section{Wstęp}

Chłoniak Hodgkina (ang. Hodgkin’s Lymphoma, HL) to nowotwór układu chłonnego, wywodzący się zwykle z limfocytów B. HL stanowi około 0,5\% wszystkich zachorowań na nowotwory złośliwe w Polsce i na świecie, przy czym najczęściej występuje u młodych dorosłych [1-3]. Możliwość stosowania terapii skojarzonej, obejmującej chemioterapię (CHT) oraz radioterapię (RT) powoduje, że względne, pięcioletnie przeżycie chorych z rozpoznanym HL wynosi obecnie 70-90\% wszystkich leczonych bez względu na stopień zaawansowania choroby $[1,2,4-6]$. Wśród przyczyn wysokiej efektywności leczenia wyróżnić należy nowoczesne standardy planowania leczenia, a także ocenę stopnia zaawansowania i monitorowanie przebiegu choroby z użyciem zaawansowanych metod obrazowania. Według autorów [1,5,7-9], badanie pozytonowej tomografii emisyjnej/tomografii komputerowej z wykorzystaniem radioznacznika ${ }^{18} \mathrm{~F}-\mathrm{FDG}\left({ }^{18} \mathrm{~F}-\mathrm{FDG}\right.$ PET/ CT), stanowi metodę z wyboru w diagnostyce HL, obejmującej zarówno wykrywanie choroby i ocenę stopnia zaawansowania, jak również ocenę skuteczności leczenia w trakcie i po zakończonym postępowaniu.

\section{Cel pracy}

Celem niniejszej pracy jest charakterystyka badania PET/CT jako przydatnego narzędzia w obrazowaniu i monitorowaniu leczenia chorych z rozpoznanym HL. Wśród celów szczegółowych pracy wyróżnić należy także porównanie użyteczności PET/CT oraz innych zaawansowanych technik obrazowych w odniesieniu do aktualnej bazy piśmienniczej.

Stowa kluczowe: chtoniak Hodgina, onkologia, PET/CT

Keywords: Hodgkin's lymphoma, oncology, PET/CT

Adres do korespondencji

Roksana Zając

Student kierunku Elektroradiologia, Katedra i Zakład Elektroradiologii, Uniwersytet Medyczny im. K.Marcinkowskiego w Poznaniu e-mail: roksana.zajac4@gmail.com 


\section{Material i metoda}

W niniejszym opracowaniu dokonano analizy przydatności badania PET/CT w diagnostyce chorych onkologicznie z rozpoznanym i leczonym HL, w oparciu o dostępną bazę piśmienniczą ostatnich dziesięciu lat. Zgromadzone dane pochodzą z bazy National Center for Biotechnology Information (NCBI; Stany Zjednoczone Ameryki, 860o Rockville Pike, Bethesda MD, 20894 USA, uwzględniającej zasoby piśmiennicze Medline, PubMed, PubMed Central i innych). Autorzy manuskryptu wykorzystali narzędzia zaawansowanego wyszukiwania, uwzględniając takie słowa kluczowe jak: chłoniak Hodkinga, chloniak złośliwy, HL, onkologia, toksyczność leczenia skojarzonego. Użyte w treści pracy polskojęzyczne opracowania, pochodzą spoza ww. baz naukowych.

\section{Omówienie}

- Wykrywanie i ocena stopnia zaawansowania HL

Rozpoznania HL dokonuje się wyłącznie na podstawie badania histopatologicznego wycinka węzła chłonnego lub tkanki objętej naciekiem nowotworowym [10-12]. Zgodnie z klasyfikacją Światowej Organizacji Zdrowia (z ang. World Health Organisation, WHO), wyróżniamy dwa główne podtypy HL - postać klasyczną (ang. classical Hodgkin lymphoma, cHL), która stanowi większość (ok. 95\%) rozpoznań. Rzadszą postacią HL jest chłoniak guzkowy z przewagą limfocytów w obrazie histopatologicznym (ang. nodular lymphocyte-predominant Hodgkin lymphoma, NLPHL) [4,7,11]. W zależności od struktury, liczby i mikrośrodowiska komórek, cHL dzielimy na cztery podtypy, przedstawione w Tabeli 1.

Tabela 1. Podzial histologiczny HL

\begin{tabular}{c|c} 
Klasyczny HL & Nieklasyczny HL \\
\hline Stwardnienie guzkowe & Guzkowy (z przewagą limfocytów) \\
Postać mieszana & \\
Ubogi w limfocyty & \\
Bogaty w limfocyty &
\end{tabular}

Cechą charakterystyczną utkania histologicznego HL jest niska liczebność komórek złośliwych, z ang. Hodgkina Reed-Strernberga (HRS) oraz Hodgkina (H), stanowiących zaledwie około 1\% objętości chorobowo zmienionego węzła chłonnego, otoczonego w 99\% tzw. mikrośrodowiskiem [5,9,11]. Tworząje komórkitła, czyli m.in. prawidłowe limfocyty, makrofagi, komórki plazmatyczne, granulocyty obojętnochłonne, eozynofile, komórki tuczne oraz fibroblasty, które wspólnie tworzą warunki sprzyjające rozwojowi nowotworu, m.in. poprzez hamowanie procesu apoptozy (programowej śmierci komórki) komórek złośliwych [11,13].

\section{- PET/CT w diagnostyce HL}

Zaletą obrazowania czynnościowego jest możliwość jednoczesnej oceny zarówno budowy i lokalizacji anatomicznej badanej struktury, jak i zmian metabolicznych zachodzących w guzie nowotworowym oraz otaczających go tkankach. Dodatkowo, w krótkim czasie istnieje możliwość zobrazowania całego ciała, co ma istotne znaczenie, szczególnie w poszukiwaniu ewentualnych przerzutów nowotworowych. Zgodnie z obowiązującą od 2014r. klasyfikacją, przedstawioną w trakcie konferencji w Lugano (Szwajcaria), przeprowadzenie badania PET/CT powinno być standardem zarówno w ocenie stopnia zaawansowania, jak i w monitorowaniu postępów terapii HL [5,14,15]. Analizy otrzymanych skanów powinno dokonywać się z wykorzystaniem pięciostopniowej skali Deauville (z ang. Deauville five-point scale, 5PS) [2,5,9,14]. Szczegółowy opis struktury skali oraz kryteriów oceny stopnia zaawansowania HL przedstawiono w Tabeli 2: 
Tabela 2. Zasady stosowania kryteriów 5 PS

\begin{tabular}{|c|c|c|}
\hline Stopień & Definicja & Interpretacja \\
\hline 1 & brak wychwytu & wynik ujemny \\
\hline 2 & wychwyt $\leq$ śródpiersie & wynik ujemny \\
\hline 3 & wychwyt > śródpiersie ale $\leq$ wątroba & wynik ujemny \\
\hline 4 & wychwyt umiarkowanie wyższy od wychwytu wątroby & wynik dodatni \\
\hline 5 & $\begin{array}{l}\text { znacząco zwiększony wychwyt w porównaniu do wątroby i/lub } \\
\text { nowych zmian }\end{array}$ & wynik dodatni \\
\hline $\mathrm{X}$ & $\begin{array}{l}\text { nowy obszar wychwytu, prawdopodobnie niezwiązany z } \\
\text { chłoniakiem }\end{array}$ & \\
\hline
\end{tabular}

\section{- Ocena stopnia zaawansowania - PET/CT vs CT}

Szczegółowa ocena stopnia zaawansowania choroby (z ang. staging) jest niezbędna do zaplanowania optymalnego planu leczenia. Zgodnie z ustaleniami z Lugano, obrazowanie ${ }^{18} \mathrm{~F}-\mathrm{FDG}$ PET/CT pełni niezwykle istotną rolę w stopniowaniu HL $[5,9,16]$. Dodatkowo, znajduje ono również zastosowanie w precyzyjnym określeniu węzła chłonnego, który powinien zostać poddany biopsji i badaniu histologicznemu [17].

Zgodnie z literaturą [5,17,18], PET/CT charakteryzuje się wyższą (w porównaniu z CT) czułością oraz specyficznością w wykrywaniu HL. Według autorów [9,17], wdrożenie PET/CT w postępowanie diagnostyczne wobec chorych z rozpoznanym HL, może prowadzić do zmiany stopnia zaawansowania na wyższy (w około 15\% przypadków) lub niższy (5\% przypadków), niż sugerowały skany CT. Zjawisko to nosi nazwę z ang. stage migration [19]. Czułość PET/CT w wykrywaniu zmian przerzutowych zlokalizowanych w szpiku kostnym określana jest jako wysoka (bliska 100\%). Oznacza to, że - zgodnie z literaturą [5,16] - ${ }^{18}$ F-FDG PET/CT może zastąpić trepanobiopsję, co ogranicza liczbę wskazań do diagnostyki inwazyjnej.

\section{- Ocena skuteczności leczenia}

Celem obrazowania PET/CT we wczesnym etapie leczenia (z ang. interim PET, iPET) jest wstępna ewaluacja chorych na podstawiebadaniazmianaktywności metabolicznejw obszarze guza, wywołanej zastosowanym leczeniem. W zależności od wyniku, chorych dzieli się na grupy: osób z nowotworem chemiowrażliwym (wynik PET ujemny - brak zmian metabolicznych) lub chemioopornym (wynik PET dodatni - wyraźne zmiany metaboliczne, zwykle: wzrost aktywności metabolicznej), co pozwala na modyfikację planu leczenia [6,18,20,21]. Zgodnie z wytycznymi międzynarodowego towarzystwa European Society for Medical Oncology (ESMO), zaleca się wykonanie badania iPET po dwóch pierwszych cyklach chemioterapii w schemacie ABVD (standard w terapii pierwszego rzutu, kombinacja czterech różnych leków cytostatycznych) lub BEACOPP (eksalowany kurs CHT, złożony z 7 różnych leków) [20]. Podstawą zastosowania iPET we wczesnej ocenie chemiowrażliwości jest zjawisko remisji metabolicznej. Polega ono na zmniejszeniu aktywności metabolicznej komórek HRS i zapalnego mikrośrodowiska pod wpływem zastosowanej terapii, co zwykle poprzedza zmniejszenie objętości guza nowotworowego. Z tego powodu, w monitorowaniu postępów leczenia, szersze zastosowanie znalazły metody obrazowania czynnościowego (w porównaniu z CT) $[14,16]$.

\section{- Wykrycie wznowy nowotworowej}

Badanie PET/CT po zakończeniu terapii (ang. end of treatment PET, EOT PET) służy przede udokumentowaniu remisji choroby oraz pozwala ocenić efekty wprowadzonego leczenia. Uważa się, że ujemna wartość predykcyjna (ang. negative predictive value, NPV) tej metody wynosi blisko 100\% [10,18]. Natomiast odnotowane $\mathrm{w}$ dostępnym piśmiennictwie wartości predykcyjne dodatnie są niższe, sięgające około 90\% [10,18]. Jest to spowodowane zwiększonym wychwytem FDG nie tylko w guzie szczątkowym, 
ale również w obrębie pozostałych, nienowotworowych zmian patologicznych, jak np. stany zapalne. Aby zminimalizować wpływ wyników fałszywie dodatnich, zaleca się wykonanie badania minimum 6-8 tyg. po zakończeniu CHT oraz 3 miesiące po ostatniej frakcji RT [18]. Niemiecka grupa badawcza w analizie HD15 wykazała wysoką czułość (94\%) oraz swoistość (90\%) badania PET/CT w ocenie resztkowych ognisk HL, u chorych leczonych chemioterapią w schematach ABVD oraz BEACOPP [18]. Ponadto, badacze zasugerowali możliwość pominięcia uzupełniającej RT u pacjentów z ujemnym wynikiem EOT PET. Udowodniono, że nie wiązało się to z negatywnym wpływem na końcowy wynik leczenia (w porównaniu z chorymi poddanymi napromienianiu), a z drugiej strony, pozwalało na uniknięcie niepożądanych skutków popromiennych i skrócenie całkowitego czasu leczenia $[9,18]$.

Dotychczas nie opublikowano jednoznacznych badań wykazujących przydatność badania FDG PET/CT w poszukiwaniu wznowy HL. Zgodnie z obowiązującymi zaleceniami badanie to przeprowadza się w kolejnych latach po zakończeniu terapii wyłącznie u chorych z klinicznym podejrzeniem nawrotu choroby. W przeciwnym razie, wykonywanie kontrolnych skanów PET/CT nie jest zalecane $[17,18]$.

\section{- PET/CT przed leczeniem drugiego rzutu}

Badanie PET/CT uznawane jest również za przydatne narzędzie przy podejmowaniu decyzji o kwalifikacji chorego do leczenia drugiego rzutu. Ujemny wynik PET/CT przeprowadzonego przed podaniem wysokodawkowej CHT, wiąże się z wysoką szansą na powodzenie terapii i całkowite wyleczenie [16]. Chorzy PET-pozytywni w tym momencie są związani z 3-letnim przeżyciem wolnym od progresji (z ang. progressionfree survival, PFS) wynoszącym 31\%, w porównaniu z 75\% u osób z wynikiem ujemnym [16,17]. Dotychczas nie opublikowano jednak oficjalnych wytycznych dotyczących wykorzystania badania PET/CT w tym celu.

\section{Dyskusja}

Badanie ${ }^{18}$ F-FDG PET/CT jest ważnym narzędziem dla klinicystów wykorzystywanym w diagnozowaniu i leczeniu pacjentów z HL. Dzięki możliwości obrazowania metabolicznego, można z dużą dokładnością ocenić zmiany patologiczne węzłów chłonnych, niekiedy niemożliwe do zlokalizowania na klasycznych skanach z CT, co przekłada się na podstawienie bardziej adekwatnej diagnozy. Z racji, że HL jest jednym z najczęstszych nowotworów występujących u osób młodych, głównym celem terapii jest nie tylko całkowite wyleczenie, ale również minimalizacja szkodliwości leczenia oraz wynikających z niego skutków niepożądanych. Dzięki wstępnej selekcji chorych na postawie obrazowania iPET, u określonej grupy pacjentów można z powodzeniem zmniejszyćtoksycznośćterapii orazskrócićcałkowity czasjejtrwania. Wykazanotakże,żeu chorych zujemnym wynik iPET pominięcie RT uzupełniającej nie niosło negatywnych skutków na końcowy wynik leczenia. Z drugiej strony, z pomocą obrazowania molekularnego, można wyodrębnić pacjentów, u których dotychczas stosowana terapia okazuje się niewystarczająca. U takich osób należy rozważyć zwiększenie intensywności terapii pierwszego rzutu, aby zmniejszyć ryzyko jej niepowodzenia lub późniejszej progresji choroby [18]. Poza tym, wprowadzenie EOT PET do standardów obrazowania w przebiegu HL pozwoliło na zastąpienie dotychczas stosowanego pojęcia niepotwierdzonej całkowitej remisji (ang. unconfirmed complete remission, $\mathrm{CRu}$ ), koncepcją całkowitej remisji metabolicznej (complete metabolic remission, CMR) [22]. Dotychczas nie opublikowano jednoznacznych badań dot. przydatności PET/CT w poszukiwaniu wznowy nowotworowej, w kolejnych latach po zakończeniu terapii. Ze względu na potwierdzony badaniami pewien odsetek wyników fałszywie pozytywnych, obecnie nie jest ono zalecane w przypadku braku klinicznych objawów nawrotu choroby. Standaryzacja zasad interpretacji skanów PET/CT (w tym wprowadzenie skali 5 PS), miała kluczowe znaczenie w wykorzystaniu tej metody obrazowania w praktyce klinicznej i wprowadzeniu na szeroką skalę metody leczenia HL w oparciu o obrazowanie molekularne.

\section{Wnioski}

Badanie PET/CT stanowi istotny element zarówno procesu diagnostycznego, jak i terapeutycznego, stosowanego wobec chorych onkologicznie z rozpoznanym i leczonym chłoniakiem Hodgkina. 


\section{Konflikt interesu / Conflict of interest}

Nie występuje / None

\section{Finansowanie / Financial support}

Nie występuje / None

\section{Etyka / Ethics}

Treści przedstawione w artykule są zgodne z zasadami Deklaracji Helsińskiej, dyrektywami EU oraz ujednoliconymi wymaganiami dla czasopism biomedycznych.

\section{Piśmiennictwo/ References}

[1] Bröckelmann PJ, Böll B. Moving things forward in Hodgkin lymphoma. F10ooRes. 2018;7:F1000 Faculty Rev-1786.

[2] Hoppe RT, Advani RH, Ai WZ, Ambinder RF, Aoun P, et al. Hodgkin lymphoma, version 2.2015. J Natl Compr Canc Netw. 2015;13(5):554-586.

[3] Didkowska J, Wojciechowska U, Czaderny K, Olasek P, Ciuba A. Nowotwory złośliwe w Polsce w 2017 roku. Krajowy Rejestr Nowotworów, 2019. Dostępne na stronie: http://onkologia.org.pl/publikacje/ (dostęp z dnia 20.03.2020r.).

[4] Aldinucci D, Borghese C, Casagrande N. Formation of the Immunosuppressive Microenvironment of Classic Hodgkin Lymphoma and Therapeutic Approaches to Counter It. Int J Mol Sci. 2019;20(10):2416.

[5] Shanbhag S, Ambinder RF. Hodgkin lymphoma: A review and update on recent progress. CA Cancer J Clin. 2018;68(2):116-132.

[6] Evens AM, Kostakoglu L. The role of FDG-PET in defining prognosis of Hodgkin lymphoma for early-stage disease [published correction appears in Blood. 2015 Apr 9;125(15):2450]. Blood. 2014;124(23):33563364 .

[7] England CG, Rui L, Cai W. Lymphoma: current status of clinical and preclinical imaging with radiolabeled antibodies. Eur J Nucl Med Mol Imaging. 2017;44(3):517-532.

[8] El-Galaly TC, Mylam KJ, Brown P, et al. Positron emission tomography/computed tomography surveillance in patients with Hodgkin lymphoma in first remission has a low positive predictive value and high costs. Haematologica. 2012;97(6):931-936.

[9] Ansell SM, Armitage JO. Positron emission tomographic scans in lymphoma: convention and controversy. Mayo Clin Proc. 2012;87(6):571-580.

[10] Cheson BD, Fisher RI, Barrington SF, et al. Recommendations for initial evaluation, staging, and response assessment of Hodgkin and non-Hodgkin lymphoma: the Lugano classification. J Clin Oncol. 2014;32(27):3059-3068.

[11] Agostinelli C, Pileri S. Pathobiology of hodgkin lymphoma. Mediterr J Hematol Infect Dis. 2014;6(1):e2014040.

[12] Wróbel T, Puła B. Rozpoznawanie i leczenie chorych na Chłoniaka Hodgkina. Hematologia 2017; 8, 3: $163-176$.

[13] Piotrowski I, Kulcenty K, Suchorska W. Historia badań nad rolą zapalenia w onkologii. Zeszyty Naukowe WCO, Letters in Oncology Science 2019;16(3):119-124.

[14] Barrington SF, Kluge R. FDG PET for therapy monitoring in Hodgkin and non-Hodgkin lymphomas. Eur J Nucl Med Mol Imaging. 2017;44(Suppl 1):97-110.

[15] Nair R, Kakroo A, Bapna A, Gogia A, Vora A, et al. Management of Lymphomas: Consensus Document 2018 by an Indian Expert Group. Indian J Hematol Blood Transfus. 2018;34(3):398-421.

[16] Barrington SF, Mikhaeel NG, Kostakoglu L, Meignan M, et al. Role of imaging in the staging and response assessment of lymphoma: consensus of the International Conference on Malignant Lymphomas Imaging Working Group. J Clin Oncol. 2014;32(27):3048-3058. 
[17] Kayani I. PET/CT in Hodgkin’s Lymphoma. Springer, 2017. ISBN 978-3-319-57224-6.

[18] Subocz E, Hałka J, Dziuk M. The role of FDG-PET in Hodgkin lymphoma. Contemp Oncol (Pozn). 2017;21(2):104-114.

[19] PietrzakAK, Martenka P, Strzesak E, Pietrasz K, Heydrych A, Pisarska B, et al. Użytecznośći ograniczenia badania 18F-FDG PET/CT w diagnostyce nowotworu złośliwego przełyku. Zeszyty Naukowe WCO, Letters in Oncology Science 2020;17(1):47-51.

[20] Eichenauer D,Aleman B, André M. Hodgkin Lymphoma: ESMO Clinical Practice Guidelines. Ann Oncol (2018) 29 (Suppl 4): iv19-iv29.

[21] Coyle M, Kostakoglu L, Evens AM. The evolving role of response-adapted PET imaging in Hodgkin lymphoma. Ther Adv Hematol. 2016;7(2):108-125.

[22] Lech-Marańda E, Warzocha K. Ocena stopnia zaawansowania i odpowiedzi na leczenie u chorych na chłoniaka Hodgkina i chłoniaki nie-Hodgkina - rekomendacje Międzynarodowej Grupy Roboczej z Lugano. Hematologia 2015; 6, 3: 223-232.

\section{Tabele}

Tabela 1. Podział histologiczny HL (Źródło: Shanbhag S, Ambinder RF. Hodgkin lymphoma: A review and update on recent progress. CA Cancer J Clin. 2018;68(2):116-132)

Tabela 2. Zasady stosowania kryteriów 5PS (Źródło: Evens AM, Kostakoglu L. The role of FDG-PET in defining prognosis of Hodgkin lymphoma for early-stage disease Blood. 2014;124(23):3356-3364.) 
